\title{
Effect of Planting Sources, Cane Portions and Setts Placement Methods on Sugarcane Yield Attributing Traits
}

\author{
Shahid Ali ${ }^{1}$, Habib Akbar ${ }^{2}$, Shamsher Ali ${ }^{3 *}$, Adnan Nasim ${ }^{1}$, Muhammad Ismail ${ }^{1}$, Nur U1 Haq ${ }^{1}$ and \\ Muhammad Usman ${ }^{4}$
}

${ }^{1}$ Sugar Crops Research Institute, Mardan, Khyber Pakbtunkbwa, Pakistan; ${ }^{2}$ Department of Agronomy, The University of Agriculture, Peshawar Pakistan; ${ }^{3}$ Department of Soil and Environ Science, AMKC Mardan, The University of Agriculture, Peshawar Pakistan; ${ }^{4}$ Department of Plant Pathology, The University of Agriculture, Peshawar. Pakistan.

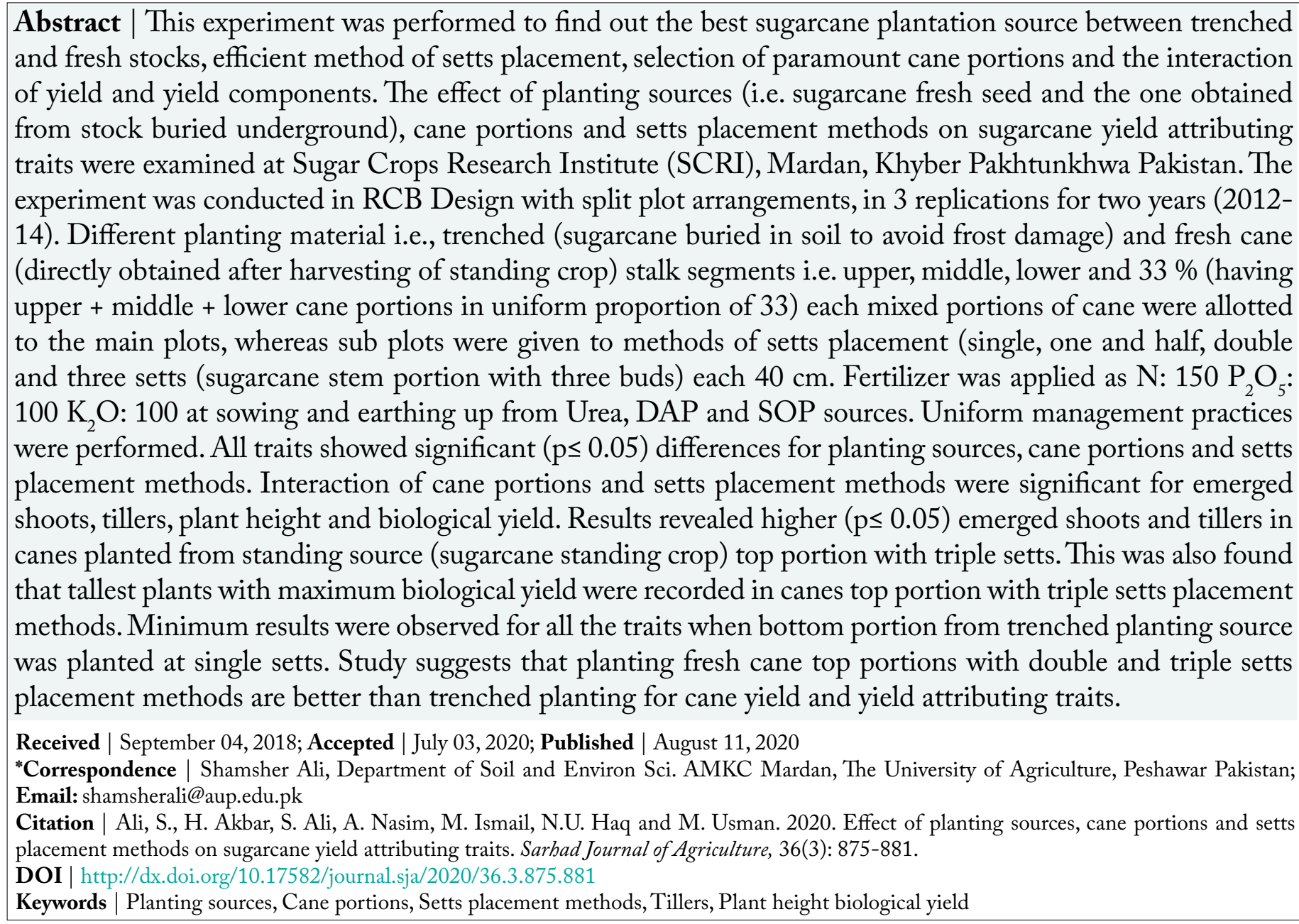

\section{Introduction}

Sugarcane (Saccharum officinarum L.) belongs Sto family Gramineae which is spread by stalk portions (Khan et al., 2013). It is believed to be the most important cash and sugar crop of the country, Pakistan (Deho et al., 2002). The main by-products of sugar industry are molasses and bagasse. The area under sugarcane crop, during 2013-14, in Pakistan was $1,172.5$ (000 ha), with a produce of $67,460.1$ 
(000 tones) yielding 57.5 tones ha $^{-1}$ (Agri. Statistics of Pak, 2013-14). During 2013-14 the sugarcane area in KPK (Khyber Pakhtunkhwa Province) was 117.38 (000 ha) with a yield of 5361.4 (000 tones ha-1) and an average cane yield at the rate of $45.67 \mathrm{t} \mathrm{ha}^{-1}$ (Agri. Statistics of Pak, 2013-14). The low cane yield in Pakistan is attributed to many factors. Selection of proper planting material, may negatively affect seed cane plantation as Deren et al. (1990) stated that delayed planted seed cane gave 20\% less cane yield than freshly planted cane in the plant cane crop and a loss of $3,000 \mathrm{~kg}$ of sugar ha-1, on account of dehydration in delayed planted seed cane. Similarly, delay in planting of seed cane reduce germination and sprouting owing to low bud moisture (Jain et al., 2009). In addition, a decreasing trend was observed in germination, tillering, sugar yield and cane yield for stale cane compared to fresh seed setts. Also in stale seed germination percentage observed was $13.95 \%, 21.72 \%, 33.13 \%, 42.56 \%$, while tillering $3.77 \%, 6.60 \%, 10.38 \%, 13.20 \%$ and cane yield $9.75 \%, 19.2 \% 3,34.75 \%, 44.55 \%$ respectively as compared to fresh seed setts, however, fresh seed setts usage ultimately quicken rate of germination, enhances tillering capacity and maximize the cane yield (Hussain et al., 2011). Likewise, sub-optimal number of setts placement can also cause decrease in cane yield. Lack of setts placement methods may decline sugar cane yield in Pakistan (Ameen et al., 2014) while germination percentage of three budded setts is higher than setts having > or $\leq$ than 3-buds. Moreover, the middle bud of a 3-budded sett has the highest germinating capacity followed by top end bud and the bottom end bud respectively. Also the middle bud have nodes on either side, its moisture resources are better protected than those of terminal buds. Similarly, the germination capacity of single bud sett is very poor owing to loss of moisture from cut ends on either side. Patel and Patel (2014) reported that normal seed rate of $100 \%$ quantity recommended buds $\mathrm{ha}^{-1}$ had a significant impact on germination, number of millable canes, cane yield (commercial cane sugar) as compared to lower seed rate of $75 \%$ recommended buds ha ${ }^{-1}$. They concluded that two and three budded setts gave higher cane yield than single budded setts. If whole cane stalk is planted without being cut into setts, usually few buds at top end germinate and the lower end buds remain inactive due to top dominance polarity (missing, buds gaps). The effect of top dominance is eliminated when cane stalk is cut into pieces. Moreover, two other factors i.e. sub-optimal number of setts placement and occurrence of severe frost in winter also have negative effects on seed cane plantation. Low seed rate is the most limiting factor for decreased yield in Pakistan (Naeem et al., 2007). Bottom portion of sugarcane results in lower germination and emergence than top and middle segments when used as planting material (Sime, 2013).

Several factors contribute to the stand establishment and cane yield. For instance, the sugarcane fresh segments resulted in better crop stand and yield as compared to other planting sources e.g. sugarcane stock obtained from trench or stored aboveground under proper sheds) (Ahmad et al., 2013). Moreover, the gaps in sugarcane crop usually are the result of using seed with damaged buds, more elongated internodes and pest infestation. The growth and yield of plant crop was enhanced by planting fresh setts and thereby filling the left gap (Singh et al., 2011). The present study was aimed to evaluate best source of planting, cane segments and methods of setts placement for cane yield and yield attributing traits.

\section{Materials and Methods}

Experiment on "Effect of planting sources, cane portions and setts placement methods on sugarcane yield attributing traits" was conducted on sugarcane plant crop at SCRI Mardan (Sugar Crops Research Institute) Khyber Pakhtunkhwa Province of Pakistan over years during 2012-14 (each experiment was planted on $12^{\text {th }}$ March) using RCB design with split plot in three repeats. First experiment was conducted on sugarcane plant crop and the second experiment on the ratoon obtained from the same crop. The size of each plot was $3.6 \mathrm{~m} \mathrm{x} 4.5 \mathrm{~m}$ with 5 rows and $90 \mathrm{~cm}$ length. The soil textural class was clay loam.

Sugarcane variety CP-77/400 was planted in this experiment. Different sources of planting i.e. trenched (sugarcane seed which was stored underground in trench 5 feet deep, 8x5 feet (length $\mathrm{x}$ width)) and fresh cane (obtained from sugarcane standing crop) stalk segments upper, middle, lower portions @ $33 \%$ (i.e. having these three portions in equal percentage of 33) were allotted to main plots, whereas methods of setts (sugarcane portion with three buds) placement were given to the sub plots. Fertilizer dose of NPK at the rate $150: 100: 100 \mathrm{~kg} \mathrm{ha}^{-1}$ was applied on $12^{\text {th }}$ March 2012 and 2013 using Urea, DAP and SOP 
as sources. Nitrogen was applied in two split doses at planting (12 ${ }^{\text {th }}$ March) and at earthing up in June. Sugarcane stalks with trash, tops and roots were placed in trenches before the onset of frost (December). At planting time, the roots along with tops and trash (dried sugarcane leaves) were stripped (removed).

Uniform cultural practices were applied to all the experimental treatments. Data were recorded on selected traits and analyzed following (Steel et al., 1997).

Emerged shoots were noted in each treatment after 30 days of plantation and then converted to emerged shoots $\mathrm{ha}^{-1}$. Tillers/Culm $\mathrm{m}^{-2}$ were recorded by counting the number of tillers (shoots) randomly at 3 spots each in three central rows after two months of plantation and then averaged. i.e., $3 \times 1 \times 0.9=2.7$ $\mathrm{m}^{2}$. Biological yield was measured by selecting ten randomly selected stalks from each treatment. The stalks were tagged and then measured from the soil surface to the top node dewlap of the plant at the time of harvest with the help of meter rod and then averaged. All unstripped stalks (stalks along with tops and trash) of the three central rows were weighed with the help of scale before stripping trash and removing the tops and converted to tones $\mathrm{ha}^{-1}$.

Biological yield $\left(\mathrm{tha}^{-1}\right)=\frac{\text { Biological yield in } \mathrm{kg} \times 10,000 \mathrm{~m}^{2}}{3 \text { rows } \mathrm{R}-\mathrm{R}(.9 \mathrm{~m}) \times \text { row length }(3.6 \mathrm{~m})=(9.72 \mathrm{~m} 2)} \times 1000$

\section{Results and Discussion}

Emergence is believed to be the most vital phase in the life cycle of any plant. Emerged shoots per hectare were significantly $(\mathrm{P} \leq 0.05)$ affected by planting sources, cane portions and setts placement methods (Table 1). Mean results showed that maximum emerged shoots (82864) were recorded in standing source as compared to minimum (78691) emerged shoots in trenched planting source. Mean higher emerged shoots (90972) were observed in cane top portions while lower emerged shoots (72518) were noticed for cane bottom portion (Figure 1). The results for triple placed setts revealed a maximum average emerged shoots of 125270 while single placed setts data showed a minimum shoots emergence of 44894 only (Figure 1). The top and middle portions of sugarcane contain cells of primordial nature. These cells have enzymes and thus activated during sprouting. Lower emerged shoots at lower cane segments may be attributed to growth inhibitors with age factor of the buds. Aged buds affects sprouting due to internal physiological condition (growth inhibitors) (Subbaro and Prasad, 2010). Cane top portion followed by middle revealed comparatively high sprouting and emerged shoots when compared with the lower cane portion (Sime, 2013) which are in agreement with the current study. Greater shoot population might be due to the better germination of planted buds. Bashir et al. (2000) observed that positive relationship between seeding density and emerged shoots of sugarcane. Mohanthy and Nayak (2011) recorded that highest germination percentage in setts having more buds. Recommended number of setts had a momentous effect on the germination than comparatively lesser placed setts (Patel and Patel, 2014). The reduced emerged shoots may also be attributed to lower moisture content in bud (Jain et al., 2009). The data for interaction effect (CP x SPM) gave emerged shoots $\mathrm{ha}^{-1}$ from the top cane segments under the triple placed setts, while the single placed setts method revealed sub-optimum emergence of shoots ha ${ }^{-1}$ for the lower cane segments.

Table 1: Emerged shoots $\left(h a^{-1}\right)$ and tillers $\left(m^{-2}\right)$ of sugarcane as affected by planting sources, cane segments and methods of setts placement during 2012-14.

Planting Ssources (PS) Emerged shoots $\left(\mathrm{ha}^{-1}\right)$ Tillers $\left(\mathbf{m}^{-2}\right)$

Standing (S)

82864 a

26.8 a

Trenched ( $\mathrm{T}$ )

$78691 \mathrm{~b}$

$25.3 \mathrm{~b}$

Significance

**

Cane segments (CS)

Top

90972 a

$29.1 \mathrm{a}$

Middle

82176 b

$26.8 \mathrm{~b}$

Bottom

$72518 \mathrm{~d}$

$23.2 \mathrm{c}$

Mixed 33.3\% each

$77443 \mathrm{c}$

$25.1 \mathrm{~b}$

LSD (0.05)

3417

2.1

Methods of setts placement (MSP)

Single setts

$44894 \mathrm{~d}$

$16.1 \mathrm{~d}$

One and half setts

64313 b

$23.1 \mathrm{c}$

Double setts

88632 c

$31.7 \mathrm{~b}$

Triple setts

$125270 \mathrm{a}$

$33.9 \mathrm{a}$

LSD (0.05)

962

0.53

Interaction

ST x CS

ST x MSP

CS $x$ MSP

ST x CS x MSP

Means for each category followed by different letters are significantly different from each other at 5\% level of probability ns: nonsignificant. 


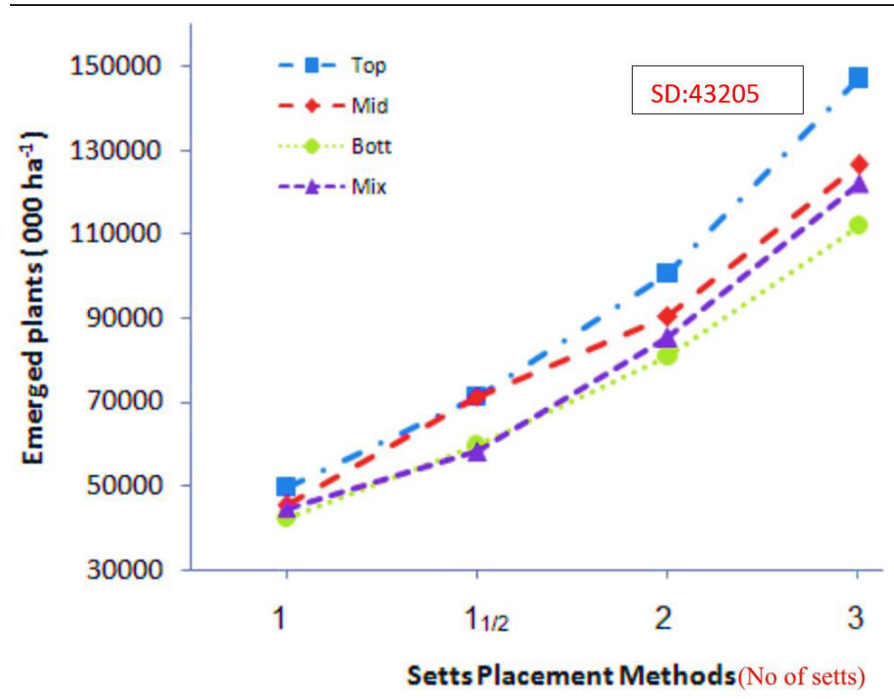

Figure 1: Emerged shoots (ha ${ }^{-1}$ ) of sugar cane as affected by cane segments and methods of setts placement.

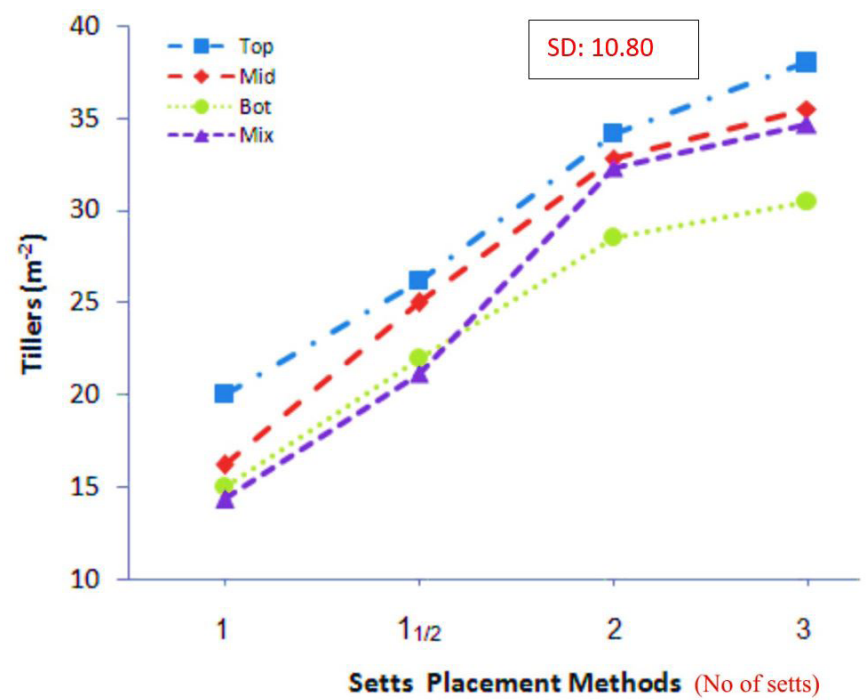

Figure 2: Tillers $\left(\mathrm{m}^{-2}\right)$ of sugar cane as effected by cane segments and methods of setts placement.

Tillering is referred to the process bywhich the branches are produced from the underground short joints of stem. As a matter of fact, the shoots are also produced on the stem; hence, tillering plays a pivotal role in final yield of sugarcane. Data given in Table 1 showed that cane portions, planting sources and methods of setts placement had significantlyvariated tillers $\mathrm{m}^{-2}$. Average tillers 26.8 and $25.3 \mathrm{~m}^{-2}$ were recorded for fresh and trench method of planting sources. Sugarcane upper segments revealed significantly high number of tillers $\left(29.1 \mathrm{~m}^{-2}\right)$ as compared to the cane lower segments with $\left(23.2 \mathrm{~m}^{-2}\right)$ number of tillers. Maximum tillers of $33.9 \mathrm{~m}^{-2}$ were observed in triple setts with minimum $\left(16.1 \mathrm{~m}^{-2}\right)$ tillers in which single setts were placed. The interactive effect of (CP x SPM) was found significant as for as tillers $\mathrm{m}^{-2}$ are concerned. The highest number of tillers was observed in the triple placed setts of the upper cane segments followed by the double placed setts methods while the single setts showed the lowest number of tillers from bottom and mix cane portions respectively (Figure 2). Highest tillering could be attributed to maximum germination percentage. Ali et al. (1999) noted that highest tillering were due to highest germination. Mohanthy and Nayak (2011) found highest germination percentage and tillers in setts having more buds. Recommended number of setts had a significant impact on germination and number of tillers than lower number of setts (Patel and Patel, 2014).

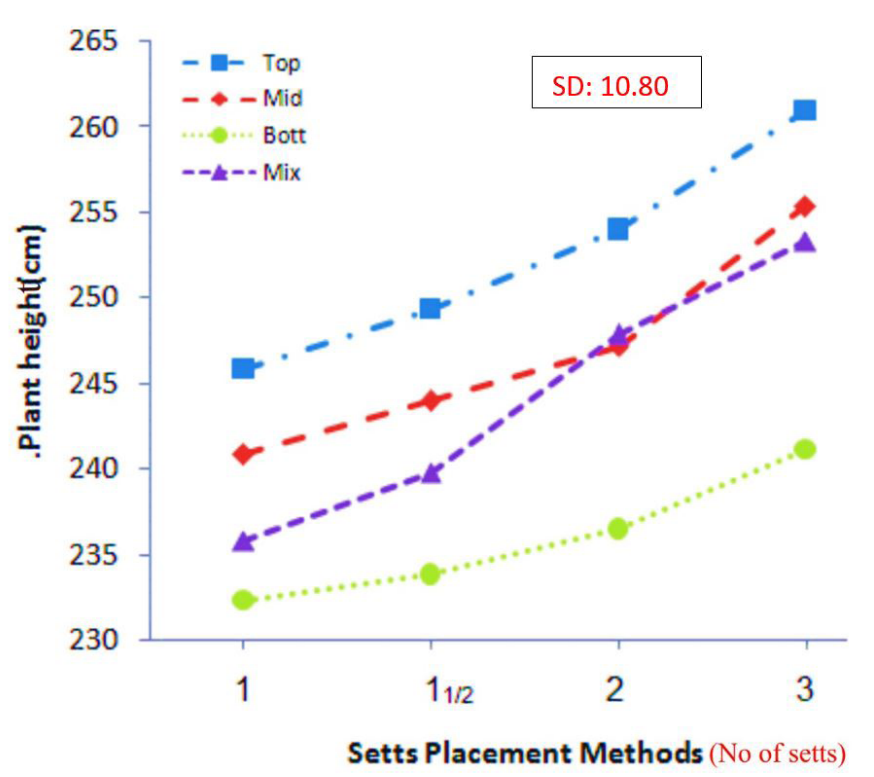

Figure 3: Plant height (cm) of sugar cane as affected by cane segments and methods of setts placement.

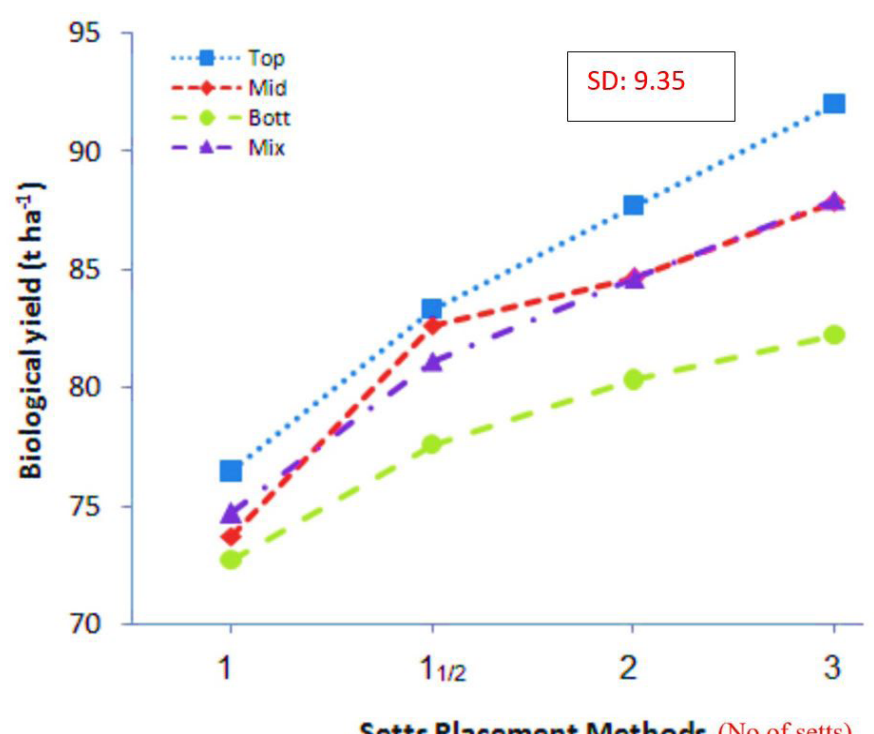

Figure 4: Biological yield ( $t h a^{-1}$ ) of sugar cane as affected by cane segments and methods of setts placement.

Plant height is a combination of better crop growing conditions and varietal characteristics. It contributes enormously to increase crop biomass. Sugarcane segments and methods of setts placement had a 
significant effect on plant height as shown in Table 2. Mean maximum taller plants $(251.2 \mathrm{~cm})$ were observed in upper cane segments while the lowest plant height of $234.6 \mathrm{~cm}$ was found in lower cane segments. This may be attributed to rapid sprouting of the buds of upper and middle portion in comparison with the lower portion. Worku (1992) found that upper segments of sugarcane give optimum germination and requires short time for sprouting than lower portion. Highest plant height might be ascribed to better utilization of water and nutrients for growth and development of canes (Mahmood et al., 2007). Average higher plant height of $251.4 \mathrm{~cm}$ was found in triple placed setts when compared with the lower plant height of 237.9 $\mathrm{cm}$ under the single placed setts. The inter or intra competition of plants for water, light, and absorption of nutrients becomes sufficiently high thereby affecting plant height. Maximum cane length was recorded in three sets than one and two sets (Shukla and Menhilal, 2003). Sugarcane plant height can be significantly affected by the different methods of setts placement (Somoro et al., 2009). The interaction effect of cane segments and method of setts placement showed that plant height was maximum in triple placed setts having cane upper segments as compared to least plant height in single setts placement (Figure 3).

The data in Table 2 revealed that biological yield was affected significantly by cane stalk segments and methods of setts placement. The average maximum biological yield of 84.4 tonnes $\mathrm{ha}^{-1}$ were noted for cane top portions while average lower (77.5 tonnes $\left.\mathrm{ha}^{-1}\right)$ biological yield recorded in cane lower portion. Mean high biological yield of 86.7 tonnes ha $^{-1}$ was recorded for plants under triple placed setts when compared with the lower biological yield of $74.2 \mathrm{t} \mathrm{ha}^{-1}$ in single setts placement. The data for the interaction effect of CP x SPM revealed that biological yield has been significantly affected over the years. Higher biological yield was found in cane upper segment of triple placed setts. Increased biological yield could be due to short internodes, maximum number of buds and higher germination percentage in cane top portion (Figure 4). Devi et al. (2011) attributed that high biological yield to improved germination percentage in two and three budded setts. Mohanthy and Nayak (2011) found a significant effect of high population density on biological yield. Hussain et al. (2011) recommended that fresh cane setts over stale cane setts for maximum biological and cane yield. Sakaigaichi et al. (2010) recorded higher number of cane stalks, maximum fresh and dry-matter yields in dense planting in both years which could be attributed to different absorption of solar radiation. The reduction per meter row spacing increased the biomass by $22 \%$ on average (Singles and Smit, 2009). The plant maturity, cultivar and annual climate induce variation in the biomass of sugar cane crop. The lower solar radiation in first year significantly lowered the tones of canes ha ${ }^{-1}(\mathrm{TCH})$ as compared to the second year (Gilbert et al., 2004).

Table 2: Plant height and biological yield of sugarcane as affected by planting sources, cane segments and methods of setts placement during 2012-14.

$\begin{array}{lll}\text { Planting Sources (PS) } & \begin{array}{l}\text { Plant height } \\ (\mathbf{c m})\end{array} & \begin{array}{l}\text { Biological yield } \\ \left(\mathbf{t ~ h a}^{-1}\right)\end{array} \\ \text { Standing (S) } & 244.9 & 81.75 \\ \text { Trenched (T) } & 242.6 & 81.02 \\ \text { Significance } & \mathrm{ns} & \mathrm{ns} \\ \text { Cane Segments (CS) } & & \\ \text { Top } & 251.2 \mathrm{a} & 84.4 \mathrm{a} \\ \text { Middle } & 245.7 \mathrm{~b} & 81.9 \mathrm{~b} \\ \text { Bottom } & 234.6 \mathrm{c} & 77.5 \mathrm{c} \\ \text { Mixed 33.3\% each } & 243.6 \mathrm{~d} & 81.7 \mathrm{~b} \\ \text { LSD (0.05) } & 5.3 & 1.08 \\ \text { Methods of Setts Placement (MSP) } & \\ \text { Single setts } & 237.9 \mathrm{~d} & 74.2 \mathrm{~d} \\ \text { One and half setts } & 240.7 \mathrm{c} & 80.8 \mathrm{c} \\ \text { Double setts } & 245.0 \mathrm{~b} & 83.8 \mathrm{~b} \\ \text { Triple setts } & 251.4 \mathrm{a} & 86.7 \mathrm{a} \\ \text { LSD (0.05) } & 1.0 & 0.31 \\ \text { Interaction } & & \\ \text { ST x CS } & - & - \\ \text { ST x MSP } & - & - \\ \text { CS x MSP } & * * & * \\ \text { ST x CS x MSP } & - & -\end{array}$

Means for each category followed by different letters are significantly different from each other at $5 \%$ level of probability ns= non significant.

\section{Conclusions and Recommendations}

The overall experiment can be concluded that plantation of fresh plant's upper cane portions, obtained from plant crop, with double and triple setts placement were found best for yield and yield attributing traits. However, triple setts placement increased cane yield at increasing setts costs (Data excluded).

\section{Acknowledgments}

The financial support of Higher Education 
Commission of Pakistan (HEC) is highly acknowledged, for partial fulfillment of $\mathrm{PhD}$ studies. The authors are also thankful to the staff of SCRI for their technicality and timely provision the all types of materials for research.

\section{Novelty Statement}

The study iss unique as it also addressed the different sowing patterns of sugarcane combined with use of different plant portions for improved crop production. In addition, it also helped determine the impact of all these activities on sugarcane crop production.

\section{Author's Contribution}

Shahid Ali did the field experiment and collected data. Habib Akbar conceived the idea. Shamsher Ali did statistical analysis of the data. Adnan Nasim helped him in writing of the article. Muhammad Ismail did proof reading of the article. Nur U1 Haq and Muhammad Usman both helped in data collection.

\section{Conflict of interest}

The authors have declared no conflict of interest.

\section{References}

Agri. Statistics of Pakistan. 2013-14. Govt. of Pakistan. Ministry of National Food Security and Research (Economic Wing), Islamabad.

Ahmad, M., K.P. Baiyeri and B.C. Echezona. 2013. Effect of planting parts and potassium rate on the productivity of sugarcane (Saccharum officinarum L.). Exp. Agric. Hortic., 2(1): 23-30.

Ali, F.G., M.A. Iqbal and A.A. Chattha. 1999. Performance of some sugarcane varieties in western Punjab. Pak. Sugar. J., 145: 6-8.

Ameen, F., A. Sajjad,A.H. Makhdum and A.Imran. 2014. Sub-optimal seed rate: an important reason of low sugar cane yield in Pakistan. Int. Asian Res. J., 2 (4): 63-67.

Bashir, S., M. Saeed, A. Ghaffar, Z. Ali and R.M.Z. Khan. 2000. Analysis of economic aspects of raising autumn sugarcane at different planting patterns and seeding densities. Int. J. Agric. Biol., 2: 322-325.

Deho, N.A., H.I. Majeedano, S.D. Tunio, and A.D. Jarwar. 2002. Effect of mulching methods on weed management, growth and yield of sugarcane. Pak. Sugar J., 12(1): 11-15.
Deren, C.W., B.R. Eiland and J.D. Miller. 1990. Sugar cane yield reduction associated with delayed planting of cut seed cane. American. Society. Sugar Cane. Technol., (ASSCT). 10: 68-71.

Devi, T.C., M. Bharathalakshmi, V. Gouri, M.B.G.S. Kumari, N.V. Naidu and K.P. Rao. 2011. Studies on the effect of sett size, seed rate and sett treatment on yield and quality of sugarcane. Indian J. Sugarcane Technol., 26(2): 4-6.

Gilbert, R.A., J.M. Shine Jr, J.D. Miller, R.W. Rice and C.R. Rainbolt. 2004. The effect of year, cultivar, and time of harvest on sugar cane yields in Florida. J. Am. Soc. Sugar Cane Technol., (ASSCT) 24: 165-184.

Hussain, F., M.A. Sarwar, S. Ahmad, M.A. Ali, N. Fiaz and A.A. Chatta. 2011. Effect of stale and fresh cane setts (seed) on yield and quality of sugarcane (Saccharum officinarum L). Int. J. Agric. Appl. Sci., 3(1): 35-37.

Jain, R., S. Solomon, A.K. Shrivastava, P. Singh, C.P. Prajapati, R.K. Singh and P. Lal. 2009. Impact of harvest to planting delays on the sprouting of seed cane. Sugar Tech., 11(2): 231-233. https:// doi.org/10.1007/s12355-009-0040-6

Khan, I.A., S. Bibi, S. Yasmin, A. Khatri and N. Seema. 2013. Phenotypic and genotypic diversity investigations in sugarcane for drought tolerance and sucrose content. Pak. J. Bot., 45(2): 359-366.

Kolo, I.N., A.A. Adesiyun, S.M. Misari and M.N. Ishaq. 2005. Evaluation of top, middle and bottom stalk of sugarcane as planting material. Sugar Tech., 7(2-3): 89-92. https://doi. org/10.1007/BF02942539

Mahmood, A., M. Ishfaq, J. Iqbal and M.S. Nazar. 2007. Agronomic performance and juice quality of autumn planted sugarcane (Saccharum officinarum L.). Int. J. Agric. Biol., 9 (1): 167169.

Mohanthy, M. and P.K. Nayak. 2011. Economizing seed cane quantity by reducing sett size and bud number with sett treatment in sugarcane cultivation. Indian J. Sugarcane Technol., 26(2): 59-60.

Naeem, M.K., M.K. Bashir, B. Hussain and M. Abbas. 2007. Assessment of profitability of sugarcane crop in Faisalabad district. Pak. J. Life. Soc. Sci., 5(1-2): 30-33.

Patel, D. and R. Patel. 2014. Influence of sett size, 
seed rate and sett treatment on yield and quality of sugarcane. Bioscan Int. J. Life Sci., 9(1): 5557.

Sakaigaichi, T., Y. Terajima, T. Terauchi, N. Kato, M. Matsuoka and A. Sugimoto. 2010. Effect of dense planting on the growth and yield of forage sugar cane variety, KRF093-1, in planting cane. Japanese. J. Crop. Sci., 79(1): 1-9. https://doi. org $/ 10.1626 /$ jcs. 79.1

Shukla, S.K. and Menhilal. 2003. Effect of sett size, planting method and soil-moisture regime on growth and yield of sugarcane. Indian J. Agric. Sci., 73(10): 534-537.

Sime, M., 2013. The effect of different cane portions on sprouting, growth and yield of sugarcane (Saccharum spp. L.). Intl. J. Sci. and Res. Publ., 3(1): 1-3.

Singh, S.N., D.V. Yadav, T. Singh and G.K. Singh. 2011. Optimizing plant population density for enhancing yield of ratoon sugarcane (Saccharum officinarum L.) in sub-tropical climatic conditions. Indian J. Agric. Sci., 81(6): 571-574.
Singels, A. and M.A. Smit. 2009. Sugarcane response to row spacing-induced competition for light. Field Crops Res., 113: 149-155. https://doi.org/10.1016/j.fcr.2009.04.015

Soomro, A.F., M.Y. Arain, R.N. Panhwar, M.A. Rajput and N. Gutar. 2009. Effect of spacing and seed placement on yield and yield contributing characters of sugarcane variety thatta-10 under agro ecological conditions of Thatta. Pak. J. Sci., 17(2): 110-115.

Steel, R.G.D., J.H. Torrie and D.A. Dickey. 1997. Principles and procedures of statistics. A biometrical approach. $3^{\text {rd }}$ ed. pp. 400-428 McGraw Hill Book Co. Inc, New York.

Subbaro, M.S. and R.B. Prasad. 2010. Studies in India on the germination of sugarcane. Indian J. Plant Physiol., 3(2): 181-194

Worku, B., 1992. The influence of different portions of the stale cuttings and number of buds per setts on sprouting, tillering and yield of sugar cane. M.Sc thesis., Alemaya Univ. Agric., Ethopia. 